\title{
УДК 027.021:93(477.83)“192/3”(048.8)
}

Надрага M. C., e-mail: m.nadraga@gmail.com, ORCID ID: 0000-0003-2247-6061, Scopus Author ID: 57202450890 к.і.н., директор бібліотеки, Львівський національний медичний університет імені Данила Галицького, м. Львів

\section{ПЕДАГОГІЧНІ БІБЛІОТЕКИ ЛЬВОВА ЗА ЧАСІВ ДРУГОЇ РЕЧІ ПОСПОЛИТОЇ: ОГЛЯД ДЖЕРЕЛ}

\begin{abstract}
Анотація. У 1920-1930-х рр. значними інтелектуальними осередками національно-культурного життя на західноукраїнських землях були педагогічні бібліотеки. Українські та польські шкільні книгозбірні відіграли надзвичайно важливу роль у процесі поступального розвитку суспільства, формуванні світогляду учнівської молоді. Утворення Другої Речі Посполитої у 1918 р. послужило причиною зміни культурно-освітніх прочесів у Галичині, зокрема у Львові, який став одним із центрів духовного розвитку украӥнського та польського народів. Питання діяльності і значення педагогічних бібліотек у Львові міжвоєнного періоду тривалий час залишалося поза увагою вчених. Такі дослідження дещо активізувалися лише в останні десятиліття; вони, проте, стосуються загальних питань освіти в Австро-Угориині та Польщі. Тому мета полягає в підборі та оцінці джерельної бази для подальших студій. У ході дослідження було проаналізовано шість груп матеріалів: нормативно-правові акти центральних органів влади, розпорядження Кураторії Львівської шкільної округи; документацію бібліотек; матеріали українських та польських національно-культурних товариств, політичних партій, Української парламентської репрезентації в Польському сеймі та сенаті; мемуарну літературу; підручники, посібники та художню літературу, яка надходила до бібліотек Львова; періодичну пресу. Встановлено, щуо особливо інформативними є офійійні документи, які дозволять зрозуміти державну політику у сфері шкільництва. Цьому сприяє також аналіз наповнення бібліотечних фондів, який показав, щзо українськомовні заклади практично не підтримувалися державою.. Проте й інші джерела містять циінну інформацію для розуміння освітньо-культурних процесів у Львові міжвоєнного періоду. Зроблено висновок, щзо поєднання всіх циих джерел дозволяє максимально об'єктивно охарактеризувати особливості функціонування педагогічних бібліотек Львова у 20-30-х рр. ХХ сm.
\end{abstract}

Ключові слова: педагогічні бібліотеки, Львів, міжвоєнний період, наукові джерела.

Nadraga M. S.,

e-mail: m.nadraga@gmail.com, ORCID ID: 0000-0003-2247-6061, Scopus Author ID: 57202450890

PhD in History, director of the library of Danylo Hakytsky Lviv National Medical University, Lviv

\section{PEDAGOGICAL LIBRARIES IN LVIV OF THE PERIOD OF THE SECOND POLISH REPUBLIC: SOURCES REVIEW}

\begin{abstract}
During the 1920s and 1930s pedagogical libraries played a key role in the national and cultural life of Western Ukraine. Ukrainian and Polish libraries have played an extremely important role in the progressive development of society and in molding the of the outlook of student youth. The formation of the Second Polish Republic in 1918 caused the change in cultural and educational processes of Galicia, particularly in Lviv, which became one of the centers of spiritual development of the Ukrainian and Polish peoples. The activity and importance of pedagogical libraries in Lviv during the interwar period remained out of the scientists' attention for a long time. The studies have intensified in recent decades; however, they were related to general education issues in AustriaHungary and Poland. Therefore, the goal is to select and evaluate the sources for further studies. Six groups of materials were analyzed in the course of the study: normative-legal acts of the central authorities, instructions of the Curatorium of the Lviv school district: normative-legal acts of the central authorities, orders of the Curatorium
\end{abstract}


of the Lviv school district; materials of Ukrainian and Polish national and cultural societies and political parties, Ukrainian parliamentary representation in the Polish Sejm and Senate; memoirs; textbooks, manuals and fiction that came to Lviv libraries; periodicals. Official documents are found to be particularly informative in order to understand the state policy in the field of schooling. The analysis of the library funds proved to be very helpful. It showed that Ukrainian-language institutions practically did not have support from the state. However, other sources also contain valuable information for understanding the educational and cultural processes in Lviv during the interwar period. It is concluded that the combination of all these sources makes it possible to characterize objectively the peculiarities of functioning of pedagogical libraries in Lviv during 20-30's of the XX century.

Keywords: pedagogical libraries, Lviv, interwar period, scientific sources.

\section{DOI: https://doi.org/10.36477/2616-8510-2019-16-23}

Постановка проблеми. У 1920-1930-х рр. значними інтелектуальними осередками національнокультурного життя на західноукраїнських землях були педагогічні бібліотеки. Українські та польські шкільні книгозбірні відіграли надзвичайно важливу роль у процесі поступального розвитку суспільства, формуванні світогляду учнівської молоді. Утворення Другої Речі Посполитої у 1918 р. послужило причиною зміни культурно-освітніх процесів у Галичині, зокрема у Львові, який став одним із центрів духовного розвитку українського та польського народів.

Аналіз останніх досліджень та публікацій. Питання діяльності і значення педагогічних бібліотек у Львові міжвоєнного періоду тривалий час залишалося поза увагою вчених. Такі дослідження дещо активізувалися лише в останні десятиліття. Так, побіжно цієї проблеми торкалися у своїх дослідженнях Н. Кунанець [12] та М. Московчук [15]. Окремі відомості можна відшукати і в статтях Л. Алексієвець [1], М. Кугутяка [11] та В. Виздрика [4]. Серед іноземних досліджень варта уваги грунтовна праця польського вченого 3. Гемболюса, присвячена діяльності бібліотек у Другій Речі Посполитій [20]. Усі ці дослідження стосуються загальних питань освіти в Австро-Угорщині та Польщі. Цілісного ж систематизованого дослідження саме про шкільні біблотеки Львова поки що не існує.

Постановка завдання. Саме тому метою статті є підібрати та оцінити джерела, які дозволять максимально повно дослідити роль педагогічних бібліотек у культурному та освітньо-науковому житті міжвоєнного Львова.

Виклад основного матеріалу дослідження. Загалом усі джерела, які стосуються діяльності педагогічних бібліотек можна поділити на 7 базових груп. Першою, чи не найважливішою групою $\epsilon$ нормативно-правові акти адже будь-яка установа у своїй діяльності керується в першу чергу чинним у державі законодавством. Документи цієї групи, більшість 3 яких опублікована в періодичній пресі та урядових щорічниках [22;23], повною мірою відображають освітню політику Польської держави, відносини влади та українських національно-культурних товариств, ознайомлять із особливостями правового регулювання бібліотечної сфери у 20-х-30-х рр. ХХ ст.

Основоположні принципи суспільно-культурного устрою міжвоєнного періоду XX ст. у Польщі заклали Конституції 1921 та 1935 рр. [21], які гарантували населенню республіки право на освіту, задоволення національно-культурних потреб.

Стенографічні звіти пленарних засідань польського сейму (Sprawozdania stenograficzne Sejmu Rzeczypospolitej Polskiej [24; 25; 26; 27; 28; 29; 30; 31; 32]) відображають специфіку парламентських дебатів у вищому законодавчому органі країни $з$ питань освіти й науки. Тексти промов послів і сенаторів, інтерпеляції (запити), внесення, законопроекти, скарги, листування та інші документи, які стосувалися шкільництва, містяться також у ф. 344 («Українське національно-демократичне об’єднання») та ф. 392 («Українська парламентська репрезентація») Центрального державного історичного архіву України у м. Львові.

Варто звернути увагу також на такі документи: декрети профільного міністерства 1919-1922 pp. («Про шкільний обов'язок», «Про закладання і утримання державних початкових шкіл», «Про створення i утримання громадських початкових шкіл»), які регламентували порядок навчання у школах всіх типів та фінансування бібліотек; т. зв. «кресові закони» («Закон про деякі положення в організації шкільництва» та ін.) (1924р.), які узаконили ліквідацію іншомовних шкіл; інструкції Міністерства віровизнань і публічної освіти (1925 р.) щодо організації бібліотек у середніх та загальноосвітніх школах; ухвали, які приведи до заснування окремих книгозбірень, зокрема Державної педагогічної бібліотеки у Львові (1925р.); 
результати шкільних плебісцитів 1925 р., 1932 р., 1937 р.; програми навчання для середніх шкіл та гімназій, які побачили світ у 1920-х-1930-х рр.; інструкції Міністерства віровизнань і освіти (1937 р.) щодо функціонування шкільних бібліотек, спрямовані на узгодження роботи шкільних бібліотек з новими навчальними програмами; розпорядження профільного міністерства щодо змін деяких постанов в організації шкільництва (1938р.) та ін.

Надзвичайно важливим джерелом є документи Кураторії Львівської шкільної округи (друга група джерел), утвореної 4 червня 1920 р. згідно з розпорядженням Міністерства народної освіти і релігійних культів. Майже всі вони зберігаються у Центральному державному історичному архіві України у м. Львові (фонд 179 «Кураторія Львівської шкільної округи»). Це, зокрема, такі групи документів:

- розпорядження куратора шкільної округи щодо утворення / реорганізації педагогічних книгозбірень;

- кореспонденція між інспекторами, дирекцією шкіл, громадськими інституціями;

- листи куратора, дирекції бібліотек щодо дарів для книгозбірень;

- річні звіти бібліотек про науково-видавничу та організаційну діяльність книгозбірень;

- протоколи перевірки педагогічних бібліотек;

- перелік придбаних книг.

Ці матеріали містять невідомі факти, які реконструюють механізми полонізації українського шкільництва, розкривають видавничу та наукову діяльність бібліотек, ознайомлюють із заходами української громадськості, які спрямовувалися на вихід у світ підручників і посібників.

Крім архівосховищ, окреслені окремі групи з перелічених документів можна знайти на сторінках спеціалізованого друкованого органу Кураторії Львівської шкільної округи [19], а також місцевій періодичній пресі, журналісти якої із зацікавленням спостерігали за нововведеннями шкільних чиновників. Для прикладу відзначимо, що наприкінці 1927 р. Кураторія Львівської шкільної округи спеціально розглядала питання про стан бібліотек у загальноосвітніх школах, після чого було проведено інвентаризацію бібліотек державних і приватних шкіл. Окреслені заходи викликали жваве обговорення на сторінках преси, посилили увагу громадськості до педагогічних книгозбірень.

Третя група джерел - внутрішня документація бібліотек та навчальних закладів, при яких вони створювалися та функціонували. Передусім це правила внутрішнього трудового розпорядку, інвентарні та дарчі книги, документи, де фіксувалася інформація про придбані бібліотекою видання, бібліографічні картки тощо. Не менше зацікавлення викликають звіти шкільних бібліотек, звідомлення 3 діяльності бібліотек, створених при національно-культурних товариствах, а також матеріали анкетувань учнів львівських шкіл, які дозволяють встановити їх читацькі інтереси та рівень задоволення обслуговуванням у шкільній книгозбірні.

Четверта група матеріалів (документи культурно-освітніх організацій, учительських товариств, політичних партій) значною мірою представлена в архівосховищах ЦДІАЛ України. До цієї групи можна віднести щорічні звіти, інформативні календарі, заклики до громадськості з проханням пожертвувати кошти або ж книги до бібліотек, листування, доповідні записки директорів бібліотеки про ії стан, протоколи ревізійної комісії, картки обліку сплати членських внесків, книги реєстрації членів, різноманітні заяви, звіти про надходження до бібліотеки обов'язкового примірника, тощо. Всі ці документи дають змогу детально ознайомитися з розгортанням національно-культурного руху українців, діяльністю українських політичних партій та громадських організацій у галузі шкільництва та бібліотечної справи.

Багато інформації про діяльність педагогічних бібліотек міститься у мемуарах, які складають п’яту групу джерел. Бібліотечна справа у Другій Речі Посполитій розглядається українськими політиками, громадськими діячами, педагогами в контексті суспільно-політичних процесів (І. Макух «На народній службі» [14]), суспільно-культурних перипетій (І. Крип’якевич «Спогади» [10]), розвитку шкільництва (С. Шах «Львів - місто моєї молодости» [17], «Ювілейна книга Української Академічної Гімназії у Львові. На 100-річчя першого українського іспиту зрілости (1878-1978)» [18], «Пропам’ятна книга гімназії Сестер Василіянок у Львові» [16] та ін.). Більшість авторів спогадів наголошують на незадовільному стані розвитку бібліотечної справи у міжвоєнній Польщі, відсутності коштів на комплектування бібліотек національнокультурних товариств, намаганні полонізувати шкільництво, наповнити бібліотеки виключно польськомовними книгами та підручниками (В. Лев «Програми навчання, навчальний матеріял, метода» [13]).

Шосту групу джерел становлять методичні посібники для бібліотекарів і вчителів, пропагандистська література для різних верств населення, а також підручники українською мовою, які є одним із основних 
джерел дослідження. Якщо із забезпеченням польських шкіл та бібліотек польськомовною літературою проблем практично не відчувалося, зовсім інша ситуація склалася з українськими бібліотеками. Брак коштів та відсутність підтримки від державних органів негативно впливали на видання та поширення україномовних книг. Однак, незважаючи на це, українські національно-культурні товариства зробили помітний внесок у справу видання педагогічної та науково-популярної літератури свого часу, сприяючи розвиткові національного шкільництва.

Останньою, сьомою групою джерел до дослідження педагогічних бібліотек $є$ періодична преса. На 1930 рік у Польщі виходили друком 285 часописів, з них тільки два - українські. 3i 1674 газет - 157 «жидівських», 84 українські, 26 білоруських та 2 литовські [9]. Для зручності її умовно можна поділити на три підгрупи: 1) часописи політичних партій; 2) газети педагогічних, національно-культурних учительських товариств; 3) вузькоспеціалізовані видання, орієнтовані на бібліотекарів.

Періодичні видання політичних партій, громадсько-політичних організацій у міжвоєнний період XX ст. приділяли чимало уваги проблемам шкільництва, розвитку бібліотечної справи. Для дослідження педагогічних бібліотек корисними є матеріали газет «Діло», «Свобода», «Громадський голос», «Новий час», «Мета», «Нова зоря», «Батьківщина», «Український голос», «Gazeta Polska», «Kurier Lwowski» таін.

Редколегії цих видань усвідомлювали значення бібліотек, шкільництва для піднесення національнокультурного рівня населення, тому незалежно від політичних уподобань висвітлювали заходи влади, а також політичні акції, спрямовані на підтримку української школи та бібліотеки у краї. Польська преса здебільшого обмежувалася статистичними матеріалами, історичними довідками про книгозбірні Львова, проблемами організаційного характеру.

Цікавими та різноплановими $є$ часописи національно-культурних товариств. Газети «Учитель», «Учительське слово», «Наша школа», «Рідна школа», «Життя і знання» висвітлювали численні проблеми в організації навчального процесу та бібліотечної справи. Часописи також містили інформацію про шкільну статистику, відображали відомості про кількість українських початкових та середніх шкіл та ін. Видання публікували пізнавальні статті на кшталт: «Відки взяти грошей на ведення бібліотеки» [2], «Закладайте шкільні бібліотеки» [7], «Від чого залежить лад у бібліотеці» [6], «Виклад про шкільні бібліотеки для молоді» [5], «Як заохотити учеников до читаня книжок» [8], «Справа бібліотек при кружках Рідної Школи» [3] та ін.

Окремо варто виділити вузькоспеціалізовану пресу, на сторінках якої коментувалися закони, розпорядження профільного міністерства, інструкції Кураторії Львівської шкільної округи, а також публікувалися статті педагогічно-теоретичного характеру [15].

Висновки і перспективи подальших досліджень у даному напрямі. Таким чином, усі джерельні матеріали, які висвітлюють діяльність педагогічних бібліотек, можна структурувати у 7 базових груп: 1) законодавчі та інші нормативно-правові акти центральних органів влади; 2) розпорядження Кураторії Львівської шкільної округи; 3) внутрішня документація бібліотек; 4) матеріали українських та польських національно-культурних товариств, політичних партій, Української Парламентської Репрезентації в Польському сеймі та сенаті; 5) мемуарна література; 6) підручники, посібники, художня література, яка надходила до бібліотек Львова; 7) періодична преса. Їх поєднання дозволяє максимально об'єктивно охарактеризувати особливості функціонування педагогічних бібліотек Львова у Другій Речі Посполитій у 20-30-х рр. ХХ ст.

\section{ЛІТЕРАТУРА}

1. Алексієвець, Л., 2008. 'Розвиток освіти на польських землях у 1918-1926 рр.', Актуальні проблеми вітчизняної та всесвітньої історії: Наукові записки Рівненського державного гуманітарного університету : збірник наукових пращь, Рівне, вип. 14, с. 235-238.

2. Б. Ч., 1936. 'Відки взяти грошей на ведення бібліотеки', Просвіта. Місячник освіти - виховання - культури, чис. 6-7, с. $139-141$.

3. В. К., 1938. 'Справа бібліотек при кружках Рідної Школи’, Рідна школа. 1938. чис. 8, с. 140-141.

4. Виздрик В., 2011. '3 історії українського шкільництва Галичини в міжвоєнний період’, Держава та армія. Вісник Національного університету «Львівська політехніка», iss. 693, с. 176-177.

5. 'Виклад про шкільні бібліотеки для молоді' 1933. Украӥнська школа, чис. 1-2, с. 30.

6. 'Від чого залежить лад у бібліотеці', 1933. Життя $і$ знання, чис. 2, с. 63.

7. 'Закладайте шкільні бібліотеки', 1925. Українське Слово, чис. 10, с. 8-18.

8. Клин О., 1931. 'Як заохотити учеников до читаня книжок', Учитель. чис. 4, с. 179 - 180

9. 'Книжка й газета в маси', 1934. Громадський голос, чис. 39, с. 2.

10. Крип’якевич І., 2001. 'Спогади', Україна: культурна спадщина, наиіональна свідомість, державність. Іван 
Крип'якевич у родинній традиції, науці, суспільстві. Львів, вип. 8, с. 13-46.

11. Кугутяк М.; 1993. 'Галичина: сторінки історії. Нарис суспільно-політичного руху (ХІХ ст. - 1939 р.)', ІваноФранківськ, 200 с.

12. Кунанець Н., 2010. 'Наукові бібліотеки Львова (1784 - 1939 рр.): особливості становлення і розвитку, формування фондів та колекцій', Львів, 244 с.

13. Лев В., 1980. 'Програми навчання, навчальний матеріял, метода' Пропам'ятна книга гімназї Сестер Василіянок у Львові, Нью-Йорк ; Париж ; Сідней ; Торонто, с. 40 - 51.

14. Макух I., 2001. 'На народній службі: Спогади', Київ, 70 с.

15. Московчук М., 2014. 'Товариство «Взаїмна поміч українського вчительства» у суспільно-культурному житті Галичини (1905 - 1939)', Львів, 135 с.

16. 'Пропам’ятна книга гімназії Сестер Василіянок у Львові', 1980. Нью-Йок ; Париж ; Сідней ; Торонто, 334 с.

17. Шах С., 2010. ‘Львів - місто моєї молодости. Цісарсько-Королівська Академічна Гімназія’, Львів, 239 с.

18. 'Ювілейна книга Української Академічної Гімназії у Львові: На 100-річчя першого українського іспиту зрілости (1878 - 1978)', 1978. Філядельфія; Мюнхен, 611 с.

19. 'Dziennik Urzędowy Kuratorium okręgu szkolnego we Lwowie Lwowskiego', 1925-1939. Lwów.

20. Gębolys Z., 2012. 'Biblioteki mniejszości niemieckiej w II Rzeczypospolitej’, Katowice, 538 s.

21. 'Konstytucja Rzeczypospolitej Polskiej z dnia 23 kwietnia 1935 r.', 1935. Warszawa, 182 s.

22. 'Państwowa Bibljoteka Pedagogiczna', 1933. Dziennik Urzędowy Kuratorium Okręgu Szkolnego Lwowskiego., № 11, s. 487.

23. 'Państwowa Biblioteka Pedagogiczna we Lwowie', 1932. Dziennik Urzędowy Kuratorium Okręgu Szkolnego Lwowskiego, № 2, s. 124.

24. 'Sprawozdanie stenograficzne Sejmu. Kadencja IV. Sejm Rzeczypospolitej Polskiej. Sesja nadzwyczajna. 1 posiedzenia w dniach 4 i 5 października 1935 r.', 1935. Ł. 1, 30.

25. 'Sprawozdanie stenograficzne Sejmu. Kadencja IV. Sejm Rzeczypospolitej Polskiej. 4 posiedzenia w dniach 5 i 6 grudnia 1935 r.', 1935. Ł. 1, 146.

26. 'Sprawozdanie stenograficzne Sejmu. Kadencja IV. Sejm Rzeczypospolitej Polskiej. 10 posiedzenia w dniach 17 lutego 1936 r.', 1936. Ł. 1, 114.

27. 'Sprawozdanie stenograficzne Sejmu. Kadencja IV. Sejm Rzeczypospolitej Polskiej. 37 posiedzenia w dniach 11 lutego 1937 r.', 1937. Ł. 1, 84.

28. 'Sprawozdanie stenograficzne Sejmu. Kadencja IV. Sejm Rzeczypospolitej Polskiej. 75 posiedzenia w dniach 23 lutego 1938 r.', 1938. Ł. 1, 99.

29. Sprawozdanie stenograficzne Sejmu. Kadencja V. Sejm Rzeczypospolitej Polskiej. 3 posiedzenia w dniach 3 grudnia 1938 r.', 1938. Ł. 1, 109.

30. 'Sprawozdanie z czynności Zarządu «Koła Pań» Towarzystwa Szkoły Ludowej we Lwowie. 1929', 1930. Lwów, 8 s.

31. 'Sprawozdanie z czynności Zarządu «Koła Pań» Towarzystwa Szkoły Ludowej we Lwowie. 1934', 1934. Lwów, 24 s. 32. 'Sprawozdanie z czynności Zarządu «Koła Pań» Towarzystwa Szkoły Ludowej we Lwowie. 1935', 1935. Lwów, 24 s.

\section{REFERENCES}

1. Aleksiievets, L., 2008. 'Rozvytok osvity na polskykh zemliakh u 1918-1926 rr. (Development of education in the Polish lands in 1918-1926)', Aktualni problemy vitchyznianoi ta vsesvitnoi istorii: Naukovi zapysky Rivnenskoho derzhavnoho humanitarnoho universytetu : zbirnyk naukovykh prats, Rivne, vyp. 14, s. 235-238.

2. B. Ch., 1936. 'Vidky vziaty hroshei na vedennia biblioteky (Where to get money for library maintenance)', Prosvita. Misiachnyk osvity - vykhovannia - kultury, chys. 6-7, s. $139-141$.

3. V. K., 1938. 'Sprava bibliotek pry kruzhkakh Ridnoi Shkoly (The case of libraries under the circles of the Native School)', Ridna shkola, chys. 8, s. 140-141.

4. Vyzdryk V., 2011. 'Z istorii ukrainskoho shkilnytstva Halychyny v mizhvoiennyi period (From the History of Ukrainian Schooling in Galicia in the Interwar Period)', Derzhava ta armiia. Visnyk Natsionalnoho universytetu «Lvivska politekhnika», iss. 693, s. 176-177.

5. 'Vyklad pro shkilni biblioteky dlia molodi (A description of school libraries for youth)', 1933. Ukrainska shkola, chys. 1-2, s. 30 .

6. 'Vid choho zalezhyt lad u bibliotetsi (What determines the order in the library)', 1933. Zhyttia i znannia, chys. 2 , c. 63.

7. 'Zakladaite shkilni biblioteky (Establish libraries)', 1925. Ukrainske Slovo, chys. 10, s. 8-18.

8. Klyn O., 1931. 'Iak zaokhotyty uchenykov do chytania knyzhok (How to encourage students to read books)', Uchytel, chys. 4, s. $179-180$.

9. 'Knyzhka y hazeta $\mathrm{v}$ masy (Book and newspaper to the masses)', 1934. Hromadskyi holos, chys. 39 , s. 2.

10. Krypiakevych I., 2001. 'Spohady (Memoirs)', Ukraina: kulturna spadshchyna, natsionalna svidomist, derzhavnist. Ivan Krypiakevych u rodynnii tradytsii, nautsi, suspilstvi. Lviv, vyp. 8, s. 13-46.

11. Kuhutiak M.; 1993. 'Halychyna: storinky istorii. Narys suspilno-politychnoho rukhu (XIX st. - 1939 r.) (Galicia: History pages. Essay on the socio-political movement (XIX century - 1939))', Ivano-Frankivsk, $200 \mathrm{~s}$.

12. Kunanets N., 2010. 'Naukovi biblioteky Lvova (1784 - 1939 rr.): osoblyvosti stanovlennia i rozvytku, formuvannia fondiv ta kolektsii (Scientific libraries of Lviv (1784 - 1939): peculiarities of formation and development, formation of funds and collections)', Lviv, $244 \mathrm{~s}$. 
13. Lev V., 1980. 'Prohramy navchannia, navchalnyi materiial, metoda (Educational programs, study material, method)', Propamiatna knyha himnazii Sester Vasyliianok u Lvovi, Niu-York; Paryzh; Sidnei; Toronto, s. 40 - 51.

14. Makukh I., 2001. 'Na narodnii sluzhbi: Spohady (On People's Service: Memoirs)', Kyiv, 70 s.

15. Moskovchuk M., 2014. 'Tovarystvo «Vzaimna pomich ukrainskoho vchytelstva» u suspilno-kulturnomu zhytti Halychyny (1905 - 1939) (Mutual Assistance to Ukrainian Teaching» in the social and cultural life of Galicia (19051939))', Lviv, 135 s.

16. 'Propamiatna knyha himnazii Sester Vasyliianok u Lvovi (Memorial book of the Basilian Sisters' Gymnasium in Lviv)', 1980. Niu-Yok; Paryzh; Sidnei ;Toronto, 334 s.

17. Shakh S., 2010. 'Lviv - misto moiei molodosty. Tsisarsko-Korolivska Akademichna Himnaziia (Lviv is the city of my youth. Tsissar-Royal Academic Gymnasium)', Lviv, 239 s.

18. 'Iuvileina knyha Ukrainskoi Akademichnoi Himnazii u Lvovi: Na 100-richchia pershoho ukrainskoho ispytu zrilosty (1878 - 1978) (Anniversary book of the Ukrainian Academic Gymnasium in Lviv: On the 100th anniversary of the first Ukrainian maturity exam $(1878-1978))$ ', 1978. Filiadelfiia; Miunkhen, $611 \mathrm{~s}$.

19. 'Dziennik Urzędowy Kuratorium okręgu szkolnego we Lwowie Lwowskiego', 1925-1939. Lwów.

20. Gębolys Z., 2012. 'Biblioteki mniejszości niemieckiej w II Rzeczypospolitej', Katowice, 538 s.

21. 'Konstytucja Rzeczypospolitej Polskiej z dnia 23 kwietnia 1935 r.', 1935. Warszawa, 182 s.

22. 'Państwowa Bibljoteka Pedagogiczna', 1933. Dziennik Urzędowy Kuratorium Okręgu Szkolnego Lwowskiego, № 11 , s. 487.

23. 'Państwowa Biblioteka Pedagogiczna we Lwowie', 1932. Dziennik Urzędowy Kuratorium Okręgu Szkolnego Lwowskiego, № 2, s. 124.

24. 'Sprawozdanie stenograficzne Sejmu. Kadencja IV. Sejm Rzeczypospolitej Polskiej. Sesja nadzwyczajna. 1 posiedzenia w dniach 4 i 5 października 1935 r.', 1935. Ł. 1, 30.

25. 'Sprawozdanie stenograficzne Sejmu. Kadencja IV. Sejm Rzeczypospolitej Polskiej. 4 posiedzenia w dniach 5 i 6 grudnia 1935 r.', 1935 . Ł. $1,146$.

26. 'Sprawozdanie stenograficzne Sejmu. Kadencja IV. Sejm Rzeczypospolitej Polskiej. 10 posiedzenia w dniach 17 lutego 1936 r.', 1936. Ł. 1, 114.

27. 'Sprawozdanie stenograficzne Sejmu. Kadencja IV. Sejm Rzeczypospolitej Polskiej. 37 posiedzenia w dniach 11 lutego 1937 r.', 1937. Ł. 1, 84.

28. 'Sprawozdanie stenograficzne Sejmu. Kadencja IV. Sejm Rzeczypospolitej Polskiej. 75 posiedzenia w dniach 23 lutego 1938 r.', 1938. Ł. 1, 99.

29. Sprawozdanie stenograficzne Sejmu. Kadencja V. Sejm Rzeczypospolitej Polskiej. 3 posiedzenia w dniach 3 grudnia 1938 r.', 1938. Ł. 1, 109.

30. 'Sprawozdanie z czynności Zarządu «Koła Pań» Towarzystwa Szkoły Ludowej we Lwowie. 1929', 1930. Lwów, $8 \mathrm{~s}$.

31. 'Sprawozdanie z czynności Zarządu «Koła Pań» Towarzystwa Szkoły Ludowej we Lwowie. 1934’, 1934. Lwów, $24 \mathrm{~s}$.

32. 'Sprawozdanie z czynności Zarządu «Koła Pań» Towarzystwa Szkoły Ludowej we Lwowie. 1935', 1935. Lwów, $24 \mathrm{~s}$. 